NASA Technical Memorandum 79097

(Revised)

\title{
PHOTOVOLTAIC POWER SYSTEMS \\ FOR RURAL AREAS OF \\ DEVELOPING COUNTRIES
}

Louis Rosenblum, William J. Birano,

Gerald F. Hein, and Anthony F. Ratajczak

Lewis Research Center

Cleveland, Ohio

TECHNICAL PAPER presented at the

Interregional Symposium on Solar Energy for Development sponsored by the United Nations in collaboration

with the Government of Japan

Tokyo, Japan, February 5-10, 1979 


\title{
PHOTOVOLTAIC POWER SYSTEMS FOR RURAL AREAS OF DEVELOPING COUNTRIES*
}

by Louis Rosenblum, William J. Bifano, Gerald F. Hein and Anthony F. Ratz.jczak

\author{
Lewis Research Center \\ National Aeronautics and Space Administraiion \\ Cleveland, Ohio
}

\begin{abstract}
Photovcltaic (PV) applications for rural areas of developing countries are discussed in relation to PV system technology, reliability, and present and projected cost. The information presented is derived mainly from NASA, Lewis Research Center experience with PV systems deployed with a variety of users for applications relevant to developing countries. A detailed description of two village power systems is included. Energy cost comparisons are presented for PV systems versus alternative energy sources. It is concluaed, based on present PV system technology, reliability and cost that photovoltaics provides a realistic energy option for de.eloping countries in both the near-and far-term.
\end{abstract}

\section{INIRODUCTION}

The importance of energy to the economy of nations has been underscored repeatedly in recent years. For none is energy of greater con. sequence, though, than for the people of the developing countries. Over one-third the population of the world is at, or slightly above, a subsistence level of energy consumption, i.e., $8.5 \times 10^{6}$ Btu per year per capita or about $10 \%$ of the per capita consumption of western European countries (ref. 1). Further, consumstion at the subsistence level is mainly in the form of non-commercial "fuels" (e.g., wood, crop residues, and animal wastes and human and animal labor) with an energy utilization efficiency of about one-fifth that for commercial fuel (ref. 2). Thus, the effective per capita energy consumption, adjusted to reflect "useful work," is in reality about $2 \%$ that in western Europe.

Such levels of energy consumption are characteristic of poverty at the absolute level, where life is at the margin of physical existence. In human terms it means high infant mortality, low life expectancy, 11 iteracy, chronic malnutrition, and for milions of infants less protein than is sufficient to permit optimum development of the brain (ref. $3)$. Such are the grim realities behind the abstract numbers.

Tragically, the future may promise no better for citizens of the poorest nations. A recent study of energy needs in developing countries, prepared for the U.S. Agency for International Development (ref. 1), pro.

\footnotetext{
${ }^{\star}$ Revised May 1, 1979
} 
jected the following scenario. By the turn of the century, if traditional modes of development continue (i.e., capital and energy intensive approaches patterned after the industrialized nations), oil consumption in the non-OPEC LDCs wil? grow steadily to becomc comparable to present-day $U . S$. consumption. In the same period world petroleum production will peak leading to competition for supply and rapid increase in price. The combinarion of increased costs for oil imports and debt service payments will leave many LDCs with a declining ability to exploit indigenous hjdrocarbon resources, or to stimlilate general economic growth. Consequently, "a large fraction of the 3-4 billion LDC rural population in the year 2000 will not be able to raise their energy usage above subsistence level."

There is probably no one answer for the energy dilemma of the poorest nations; rather, a mix of mutually supporting technical, institutional and developmental approaches will be required. Among the technical approaches which could ameliorate the present situation, and avert a possibly dire future, is the more extersive use of renewable energy resources, specific. ally solar. In this regard, the direct conversion of solic energy to electricity by means of solar cells is of great intersst. Of all the solar technologies, photovoltaic (solar cell) power jystems appear to have the most flexibility for meeting a large variety of the small-scale, decentralized energy needs of rural areas in underdeveloped countries. It has been acknowledged that photovoltaic systems have many desirable features: modularity (therefore scalable in size); no moving parts; low maintenance; and a potentially lcng life. On the other hand, uncertainty has been expressed concerning capital (or first) costs and system reliability.

From 1958 to recent years the major application of solar cells has been in space where it is the power system of choice, supplying watts to several kilowatts of power to hundreds of spacecraft. In the 1960s, Japan successfully employed solar cells in a number of instrument, communication, and navigational aid applications; total peak power employed in all applications to 1976 was $22 \mathrm{~kW}$ (ref. 4). From the early 1970s, U.S. firms began marketing photovoltaic power systems for communications, instrument, and corrosion protection applications. By 1975 the annual terrestrial solar cell production in the U.S. Was about $100 \mathrm{~kW}$ peak. Production has approximately doubled each succeeding year, partly under the impetus of the newly created national photovoltaic program and partly as a result of an expanding commercial applications market. In this same period, 1975-78, solar cell module price has dropped from about $\$ 35 /$ Watt peak to $\$ 13 /$ Watt peak, both in 1978 dollars.

The purpose of this paper is to discuss (1) photovoltaic applications for rural areas of developing countries, (2) the status of photovoltaic sysiem technology, (3) reliability, and (4) present and projected system costs. Understandably, for proprietary reasons, detalled information from commercial organizations on applications, systems and cost is 
not generaily available. Therefore, the material presented here is drawn almost exilusively from the many and vaiied terrestrial photovoltaic systems developed by the NASA Lewis Research Center (leeRC) since 1970. The buik of this application development was carried out as part of the Department of Energy (DOE) Photovoltaic Tests and Applicictions rroject, managed by LeRC.

It is hoped that this paper will further the understanding of development planners, public administrators, and donor agencies concerning this potentially consequential energy option.

\section{APPLICATIONS}

From the user's point of view, a solar photovoltaic (PV) power system is not an end in itself; it only provides an enabling commodity, namely, electricity'. Qased on the user's needs, the electricity can be employed to power a host of services. For purposes of organization we can arrange these services into application categories. One such category is water pumping. Applications can be subdivided by use. In the case of water pumping, for example, the suhdivisions might be potable water and crop irrigation. For each application there is an associated device or mechanism, the electricaliy powered "load," which provides the desired service. Referring to the water pumping example, the "load" would be an electric motor/pump assembly.

Listed in Table 1 are several major photovoltaic applications and uses pertinent to rural areas of underdeveloped countries. The fiv system power level associated with typical uses is also displayed. In estimating power ievel, a solar insolation factor was used representative of insolation found in countries l ying between $30^{\circ} \mathrm{N}$ and $30^{\circ} \mathrm{S}$ latitude, namely, one watt $($ peak) $=1.6 \mathrm{kWH}($ electric)/year. Actual load performance data was employed.

In practice, users may desire a group of services at a single location. For this instance it is usually desirable to employ one system to power several discrete loads. We therefore have defined a category called "cluster" applications. Examples of these are village power and medical services applications. A village power application using a centrally located power system might include any or all of the following services: potable water pumping, food preservation, grain milling, home lighting, educational TV. A medical services application, likewise, might include drug and vaccine preservation, potable water pumping, and work area lightirig.

Since 1970 the LeRC has been actively engaged in developing "standalone" PV systems for near-term, cost-effective applications. In all cases, these systems were instalied in rural or remote areas and turned over to the user for operation and maintenance. A summary of the applica- 
TABLE 1. - PHOTOVOLTAIC APPLICATIONS IN RUPAL AREAS OF LDCS

\begin{tabular}{|c|c|c|}
\hline APPLICATIOH CATEGORY & IYPICAL USES & PV SYSTEM POWER REOUIREMENTS \\
\hline WATER PUMPING & $\begin{array}{l}\text { POTABLE NATER } \\
\text { IRRIGATION }\end{array}$ & $\begin{array}{l}0.08 \mathrm{~W} / \ell^{2} / D A Y \\
85 \mathrm{~K}_{p} / \mathrm{Hu}-\mathrm{m}^{\mathrm{b}} / \mathrm{LAY}\end{array}$ \\
\hline REFRIGERATION & $\begin{array}{l}\text { FOOD PRESERVATION } \\
\text { DRUG \& VACCIHE } \\
\text { PRESERVATION }\end{array}$ & $100 W_{p}$ PER 5 CU, FT, REFRIG. \\
\hline LIGHTING & $\begin{array}{l}\text { HOMES } \\
\text { WORK AREAS }\end{array}$ & $16 W_{p}$ PER 20 FL. LAMPC \\
\hline COMUNICATIONS & EDUT.ATIONAL TV & $40 W_{p} / T V S E T^{d}$ \\
\hline FOOD PREPARATIOK & $\begin{array}{l}\text { MILLING } \\
\text { DECORTICATION }\end{array}$ & $3.5 \mathrm{~K}_{\mathrm{P}} / \mathrm{KG}$ FLOUR/DAY \\
\hline COTTAGE INDUSTRY & $\begin{array}{l}\text { METAL OR WOOD } \\
\text { FORYIILE }\end{array}$ & $2.0 \mathrm{~kW}_{P} / 1 \mathrm{HP}$ WTTOR \\
\hline
\end{tabular}

3ON. TOTAL DYNGNIC HERJ.

DFOR 5M HEAD; 6O: FIELD EFFICIENEY.

CAVERAGE USE 2 HOURS PER HIGHT.

d32 WATT TV SET, 4 HOURS OPERATION/DAY.

C8 HOURS OPERATION/DAY.

\section{TABLE 2. - MASA LEWIS RESEARCH CEMTER PHOTOI gLTAIC APPLLLCATION SUMPARY}

\begin{tabular}{|c|c|c|c|c|c|}
\hline SINGLF APPLICATLONS & USE & USER & MIE OPERATIOHAL & LOCATION & POKRR LEVEL, $W_{P}$ \\
\hline COMPUNECATIOAS & EDUCATIOKA: $N$ & GOVT. INDIA & JULY 1976 & $\begin{array}{l}\text { 1) AHEDABAD, INDIA } \\
\text { 2) SWBALPVR, INDIA }\end{array}$ & $\begin{array}{l}55 \\
55\end{array}$ \\
\hline - REFRIGERATIOh & FOOD PRESERVATIOK & KAT, PARK SER. & JUNE 1976 & ISLE ROYALE, MI & 220 \\
\hline - REFRIGERATIOH & REIICAL & $\begin{array}{l}\text { VILLAGE RESIDENTS } \\
\text { PAPAGO TRIBE }\end{array}$ & JULY 1976 & SIL MAKYA, AZ & 330 \\
\hline - IASTRUKE & MEATHER DATA & MAI. MEATHER SER, & APR-SEPT 1977 & $\begin{array}{l}\text { 1) MEW MEXI(0; } \\
\text { 2) MEY YORX; 3) HAWAII: } \\
\text { 4) MUSKA; 5) MAIHE; } \\
\text { 6) FLORIDA }\end{array}$ & $75-150$ \\
\hline - hIStikir & DUST STORM KAPMIMG SICK & DEPI, TRANS-AZ & APRIL 1977 & CASA GRAYDE, AZ & 116 \\
\hline - Instrumithi & IKSECT SURVEY TRAPS & DEPI. AGRIC. & MAY 1977 & COLLEE SIATIOH, IX & $23<163$ \\
\hline - REFFIGERÁTlOh & MATER COOLER & $\begin{array}{l}\text { IMTERAGENCY } \\
\text { VISITOR CENTER }\end{array}$ & OCTOBER 1977 & LOHE PIME. CA & 446 \\
\hline \multicolumn{6}{|c|}{ CLUSIEF APPLICATUMR: } \\
\hline • FIRE LOJKOJJT & $\begin{array}{l}\text { 2-KAY RAD10, REFRIGERATOR, } \\
\text { LIGHIING, POTABLI KAIER }\end{array}$ & FORESI SERVICE & OCIOBER 1976 & $\begin{array}{l}\text { 1) PILOT PEAK, CA } \\
\text { 2) NIELOPE PEAK, CA }\end{array}$ & 294 \\
\hline - village poner & $\begin{array}{l}\text { POIABLE WAIER, LIGHTILG, } \\
\text { REFRIG, RAIION, MASHIHG } \\
\text { MACHIAE, SEWIAG MACHIHE }\end{array}$ & $\begin{array}{l}\text { VILLAGE RESIDENTS } \\
\text { PAPAGO TRIBE }\end{array}$ & DCCERBER 1978 & SCHUCRULI, AZ & 3500 \\
\hline - village poner & $\begin{array}{l}\text { POTABLI WIER, GRAIK } \\
\text { MILLIMG }\end{array}$ & VILLAGE RESIDEEITS & FEBRUARY 1979 & $\begin{array}{l}\text { IAMGAYE, UPPER VOLIA, } \\
\text { NFRICA }\end{array}$ & 1800 \\
\hline
\end{tabular}


tions deployed is given in Table 2. Although some of these applications are not of direct interest for rural areas of developing countries, e.g., instrument and highway applications, the majority constitute a sizeable body of relevant application experience germane to the needs of underdeveloped countries.

All systeins installed are operating, except for three short-term crsmonstrations - the two India Educational TV units and the seasonally used refrigerator at Isle Royale - and one weather data station which was washed to sea during a severe storm in the winter of 1978.

\section{RELIABILITY}

The silicon solar cell, a product of the well-developed semiconductor industry, is a highly reliable and stabie device when protected from the environment. Photovoltaic systems have proven extremely reliable for onboard pewer for spacecraft for over 20 years. Terrestrial solar cells are similar in many respects to space cells, except that they are manufactured usir.g lower cost techniques and are encapsulaced differently to protect them from earth environment.

Silicon solar cell modules incorporated in systems listed in Table 2 have accumulated over 623 module-years operation time. There have been only four module failures. To date, then, this experience indicates a module failure rate of only $0.0064 / \mathrm{yr}$.

System reliability is strongly dependent on system design and the selection and assembly of the components, i.e., modules, batteries, controls, regulators, structure, and wiring. Operating experience from the variety of geographically dispersed applications listcd in Table 2 indicates excellent system reliability. Only one component (non-module) failure was observed in the score of systems deployed to date; this involved a defective voltage regulator which was readily replaced.

In this regard it can be noied that a manufacturer of remote instrument equipment reports (ref. 5) that some customers now specify photovoltaic power for outdoor instrument systems, even for sites where power is available from utility lines. This is because these customers have found the outage rate greater for utility power than fo: photovoltaic systems.

\section{SYSTEMS}

A PV power system typically consists of a solar cell array, energy storage, and regulation and control devices. The solar cell array structure serves as a means of integrating the relatively small, low power, low voltage module into a usable assembly. It mechanically supports the

Basic building block: contains a number of solar cells electrically connected and encapsulated in a supporting frame. 
modules and provides routing and attachment points for the wire harness which connects modu? es and collects power from the array. Energy storage typically consists of a number of lead-acid cells connected in series and/or parallel to provide the desired voltage. Sufficient storage capacity must be provided to meet specific load requirements and to account for diurnal and seasonal variations in solar insolation. Voltage regulation is provided to protect the batteries from over-charge and excessive discharge and to protect the loads from voltage extremes.

Basically, a PV system for single application use is relatively simple from a technical point of viaw, consisting of the three elements described above. Cluster applications, because of additional control fr.dtures often required to properly manage the multiple loads, may have an added element of complexity.

For purposes of exposition, two representative village applications will be discussed below. One, Schuchuli (Arizona, U.S.), includes water pumping, lighting, refrigeration and housekeeping services. The other, Tangaye (Uprer Vilta, Africa), includes water pumping and foou preparation.

\section{Schuchuli Village Power System}

The village of Schuchuli is located on the western edge of the $2,750,000$ acre Papago Indian Reservation in southwestern Arizona. The village's 15 families (95 people) are $27 \mathrm{~km}$ (17 miles) from the nearest available electric utility power. The villager's diet has been tied to traditional (i.e., non-refrigerated) methods of food storage and preparation and includes itens such a chiii, beans, tortillas and commercially available non-perishable vegetables and canned foods. Cattle raising and wild game hunting provide an occasional supplemental source of food. Until the advent of the PV power system, water was provided by a dieselpowered pump; kerosene lamps and candles provided lighting in the homes.

On December 16, 1978, the world's first Village Photovoltaic Power System began operation, providing the residents of Schuchuli with the following services: electric power for potable water pumping; lights in the homes and community buildings; family refrigerators; and a communal washing machine and sewing machine.

The Schuchuli Village Photovoltaic Power System consists of a $3.5 \mathrm{~kW}$, 120 volt, DC PV a ray, 2380 ampere-hours of battery storage, controls, regulator and instrumentation, and an overhead electrical distribution network. The batteries and controls are located in an electrical equipment tuilding (EEB) as indicated in the block diagram of Figure 1.

The system is all $D C$ to avoid the losses associated with commercially available DC/AC inverters and to marimize zystem efficiency. The 


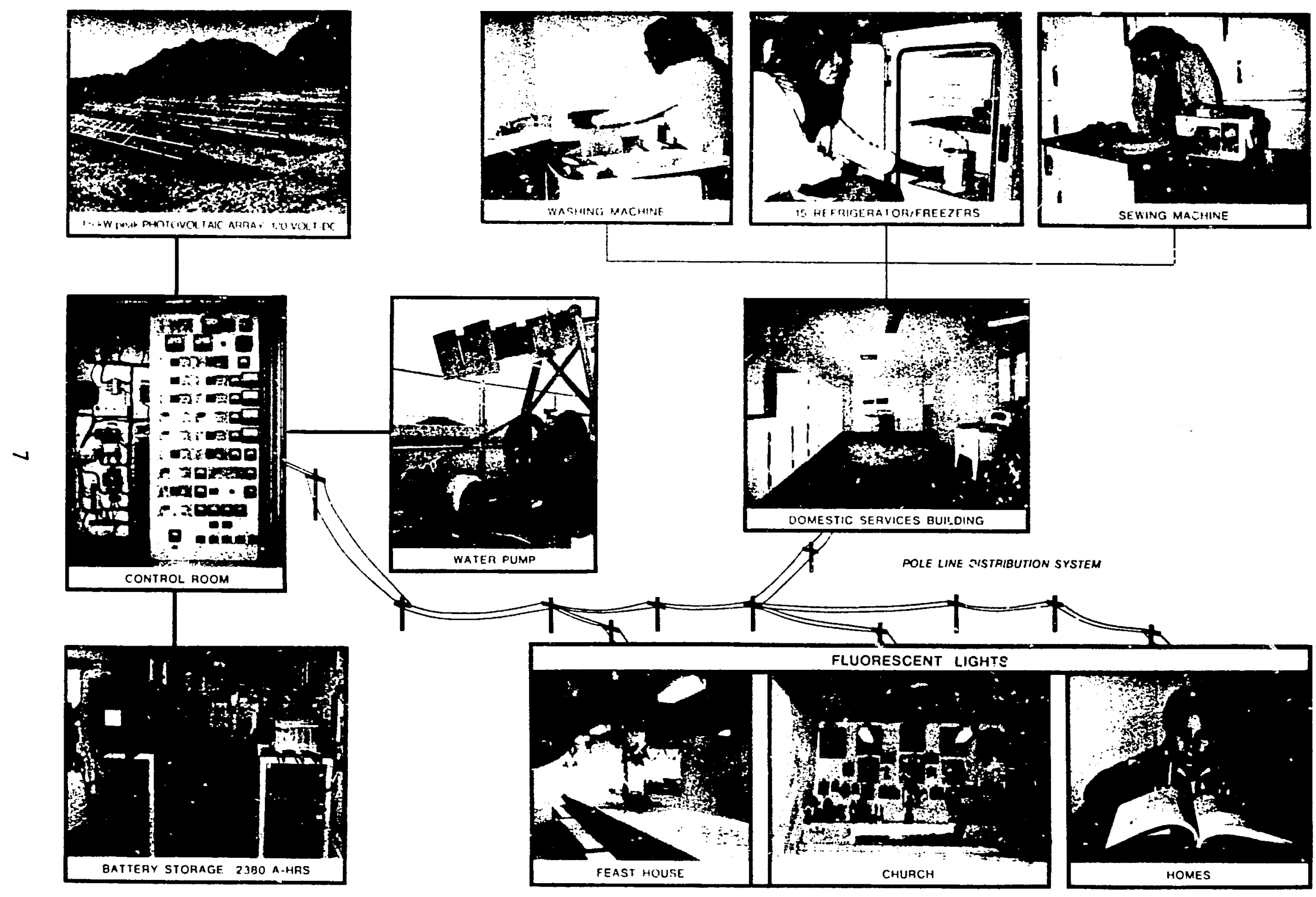

WORLC'S FRST VILLAGE PHOTOVOLTAIC, POWER, SYSTEM - PAPAGO INUIAN VILLAGE OF SCHUCHULI, ARIZONA Froure 1 
system voltage was set at 120 volts to limit distribution line losses and to enable use of commercially available DC switches and DC appliance motors. The load devices were individually selected on the basis of energy efficiency.

System design, exclusive of the overhead distribution network, was performed by LeRC. The overhead distribution network was designed by the Papago Tribal Utility Authority. A brief description of the major system components and features follows.

A 2 HP permanent magnet 120 VDC motor powers a jack pump which delivers approximately $4165 \mathrm{liter} / \mathrm{hour}$ (1100 gal/hour) into the village water distribution system which includes a 41,635 itter (11,000 galion) storage tank located approximately $365 \mathrm{~m}$ (1200 feet) from the well. A control system limits pumping to daylight hours roughly ceritered about mid-day, except for emergency situations.

A total of 47,20 watt/120 VDC fluorescent lights are installed in the village. The lights employ a special design $120 \mathrm{VDC} / 23 \mathrm{kHz}$ inverter-ballast which enables the lamp to produce the same number of lumens as a $120 \mathrm{VAC} /$ $60 \mathrm{~Hz}$ ballast.

A total of $15,0.13 \mathrm{~m}^{3}$ (4.7-cubic-foot) refrigerators (with a small freczing compartment) are installed in the domestic services building. These refrigerators are of a custom design developed by a manufacturer of marine refrigerators and are completely insulated with a minimum of 3 inches of polyurethane foam. Each has an automatic door closer and a key lock. Three refrigerators are assembled as a unit and powered from a single compressor with a 1/8 HP 120 VDC permanent magnet motor. The manufacturer reports that the duty cycle should be about $25 \%$ "on" in a 43C (110F) ambient environment based on test results from a similar unit.

A standard wringer-type washer was retrofitted with a 1/4 HP permanent magnet $1: 0$ VDC motor. A wringer-type washer was selected for overall simplicity?:.: to reduce water consumpition. The washer is connected to a cumulative timer which allows up to 12 hours per day of wasner operating time. At $1 / 2$ hour/load, this provides for washing approximately 1.75 loads/person/week.

A commercially avallable sewing machine with a $1 / 8 \mathrm{HP}, 120 \mathrm{~V}$ universal motor was also installed in the domestic services building.

A LeRC-developed computerized system simulation program was used to determine PV array size and battery cafacity. A composite hourly load profile for each month was used in the sizing calculation as was a $20 \%$ degradation of PV array output due to dirt accumulation and potential PV module encapsulari darkening, and a $\pm 20 \%$ variation of insolation from average values. Worst case battery depth-of-discharge was calculated to be $60 \%$. 
The PV array consists of $24,1.22 \mathrm{~m}-$ by $-2.44 \mathrm{~m}$ ( $4 \mathrm{ft} .-$ by- $8 \mathrm{ft}$.) panels . Each panel contains 8 modules connected in series to make up a 120 VDC series string. The panels are arranged in 3 rows of 8 and are located in a $21.3 \mathrm{~m}-\mathrm{by}-30.5 \mathrm{~m}$ ( $70 \mathrm{ft} .-\mathrm{by}-100 \mathrm{ft}$.) fenced area. Panel frame and support structure are designed to withstand $161 \mathrm{~km} / \mathrm{hr}(100 \mathrm{MPH})$ wind loads and are fabricated from commercially available hardware.

The battery consists of 52, 2380-ampere-hour capacity cells connected in series with a parallel arrangement of 4 pilot cells for load management. One pilot cell has a 1055-ampere-hour capacity and the other 3 have $310-$ ampere-hour capacities. All capacities are at a 500-hour, $25 \mathrm{C}$ (77F) discharge rate. The cells were designed for operation with PV systems and have lead-calcium plates capable of deep discharge cycle operation. The batteries are housed in a separate, vented room in the electrical equipment building.

Because of unknowns in the use of the loads and variations in insolation, a load management subsystem was incorporated into the design to (1) protect the batteries from excessive discharge and potential damage, and (2) to maintain operation of the more critical loads at the expense of less critical loads. The load management subsystem sequentially disconnects loads as the battery capacity decreases to preset levels.

At $50 \%$ depth-of-discharge, the washing and sewing machines are disconnected, at $60 \%$ the lights are disconnected, at $70 \%$ the water pump motor is disconnected, and finally at $80 \%$ depth-of-discharge the refrigerators are disconnected. As the batteries are recharged, loads are sequentially reconnected into the system in reverse order. The four pilot colls provide a method for sensing the depth-of-discharge of the 2380-amperehour cells.

System voltage is regulated by array string switching. There are relays (one per string) which connect the array strings to the main bus or open circuit the strings through a field-programmable drum relay. The drum relay is commanded to increase or decrease the number of connected strings by a controller which senses system voltage. This same drum relay is also used for the load management subsystem.

Under- and over-voltage protection is provided in addition to system voltage regulation. If system voltage exceeds the maximum allowable value, the PV array is disconnected. If system voltage drops below the minimum allowable, the loads are disconnected. Alarm lights are provided for these conditions.

Since the Schuchuli village PV power system is the firs: of its kind, it is completely instrumented to obtain a substantial amount of basic engineering data. There are two independent instrumentation subsystems; a panel meter subsystem and an automatic cassette data recorder. The 
panel meters are read daily by a village resident who 15 trained to take readings and to recognize anomalous operation. Measurements are also recorded hourly by the automatic data system. The cassettes and the panel meter data are mailed to LeRC weekly for analysis.

An overhead distribution network was installed by the Papago Tribal Utility Authority and generally follows the water distribution line, thus establishing a utility corridor around the village. The 120 VDC distribution system consists of two circuits with two No. 1 ACSR bare aluminum conductors each and a grounded fifth wire which acts as an electrostatic grid. One of the two distribution circuits provides power for all appliances in the domestic services building. The othar eircuit provides power for lights in all the other buildings.

The photovoltaic system design and installation conforms to National Electrical Codes and OSHA Safety Regulations and specifications. Additional safety features are: a $1.8 \mathrm{~m}$ ( $6 \mathrm{ft}$.)-high chain-link fence with a locked gate surrounding the array field; warning signs; and enclosed pump.

\section{Tangaye Village Power System}

The West African village of Tangaye, Upper Volta, is located about $190 \mathrm{~km}$ east of Ouagadougou, the capital city. The main occupations of its 2700 inhabitants are farming and cattle-raising and the main food crops are sorghum and millet. The men of the village perform the farming chores while women are responsible for al? aspects of family care. This includes a number of laborious and time-consiming tasks such as drawing of water and preparing of daily meals. Food prepiration, for example, involves the pounding of grain, the primary source of fand into a coarse flour using a large wooden mortar and pastle. Finer flour is obtained by stone grinding the grain by hand. This arduous task alone generally occupies about two hours per day.

As part of a project sponsored by the U.S. Agency for International Development (AID) entitlad, "Studies of Energy Needs " $n$ the Food System," a photovoltaic system powering a grain mill and water pump is currently a photovoltaic system powerifig a grain mill and water pump has been installed in the village. Operation began March 1, 1979.

The system consists of a $1.8 \mathrm{~kW}$ (peak), 120 VDC PV array, 540-amperehours of battery storage, regulator, controls, and instrumentation designed by LeRC. The PV array, located in a fenced-in area, provides power via underground cable to a control cabinet located in a nearby mill/battery building as shown in Figure 2. Storage batteries se located in one room of the building; the mill and control cabinet are in the other. An underground cable carries power from the control cabinet to the water pump. A water storage tank and dispensing facility are located near the well. The tank was designed by LeRC and procured and installed by Upper Volta AID Mission personnel. The mill/battery building was built by the men of Tangaye. 


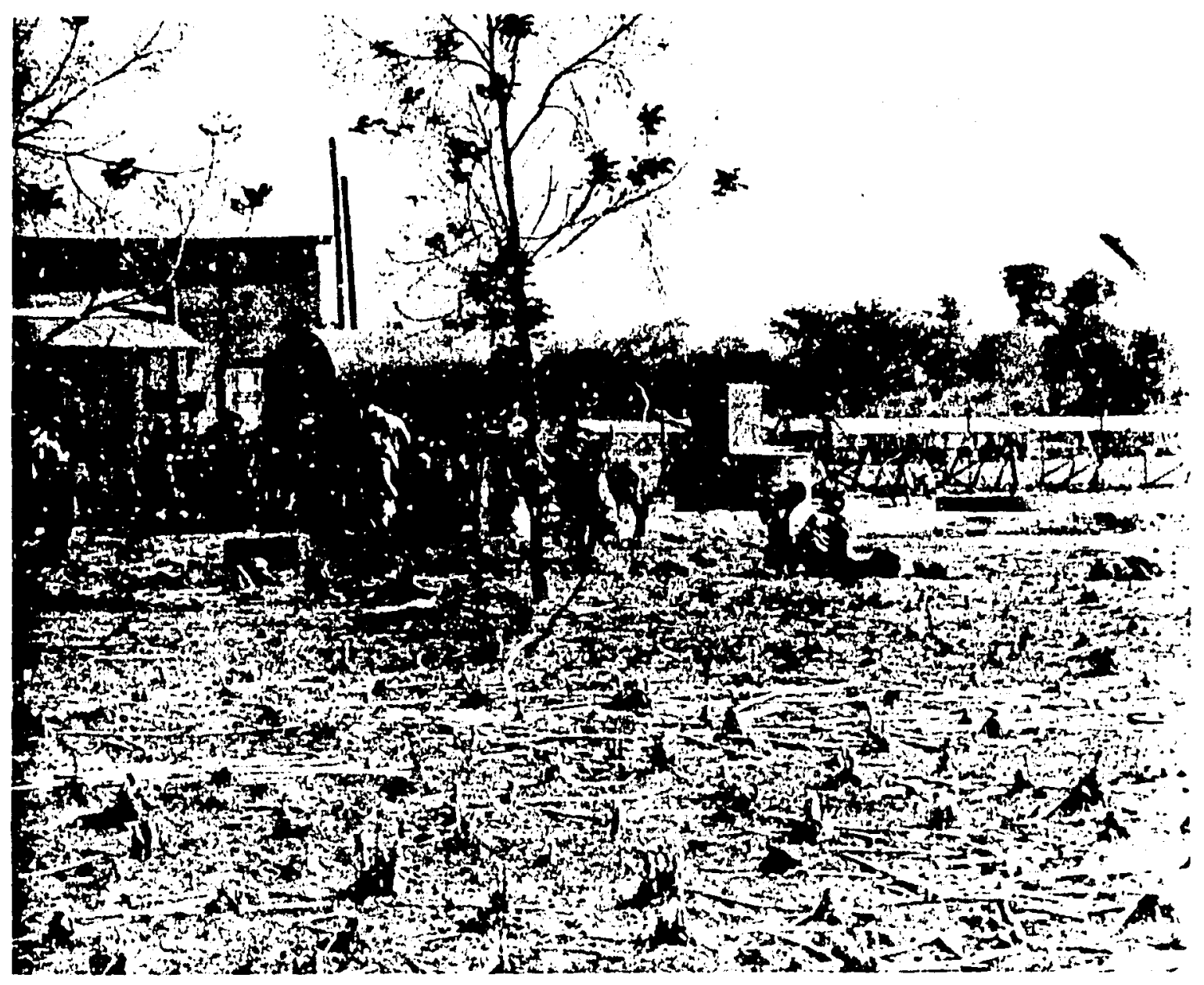

Figure 2 - Photovoltaic Power System in Tangaye, Upper Volta Mill Building, Water Tank, Well and Pump, Solar Cell Arrays

System size was established based on limitations of available funding and site specific details obtained during a visit in February 1978. The water pumping was set at 5000 liters/day based on the measured recovery rate of the well. A mill was selected to provide apprnximately $320 \mathrm{~kg} / \mathrm{day}$ of finely ground grain, enough to meet the daily requirements of about 640 families.

The system loads consist of a commercial burr mill using a $1 \mathrm{HP}$ 120 VDC motor and a positive displacement water pump with a $1 / 4$ HP 120 VDC motor. The pump is capable of delivering 1457 liters/hour at a total dynamic head of 28 meters (92 feet). The mill has a manufacturer's rated capacity of 45 to $136 \mathrm{~kg} / \mathrm{hr}$ depending on the material being ground.

The procedure used for PV array and battery sizing was the same as described previously in the section on Schuchuli. Accoroing to the computations, the battery maximum depth-of-discharge should be about $30 \%$. 
The $1.8 \mathrm{~kW}$ (peak) 120 VDC PV array consists of 12 series strings of 8 modules each. The modules are assembled into $12,1.22 \mathrm{~m}-\mathrm{by}-2.44 \mathrm{~m}$ ( $4 \mathrm{ft}$.by-8 ft.) panels (each containing 8 modules wired as 1 series string). The panels are arranged in 3 rows of 4 panels each and are located within a fenced area of $256 \mathrm{~m}^{2}\left(2755 \mathrm{ft}^{2}\right)$. Array tilt angle is $11^{\circ}$ from the horizontal year around. The panel frame and support structure are designed to withstand $161 \mathrm{~km} / \mathrm{hr}$ (100 MPH) wind loads and are fabricated from commercially avallable hardware. A separate 74 watt 12 VDC panel and a 100-ampere-hour battery will provide power for instrumentation and controls.

The battery for the 120 VDC system consists of 55, 540-ampere-hour cells designed specifically for PV systems operation. The battery cells are mounted on two single-tier racks located in a separate vented room of the milling building.

The system utilizes three control subsystems: system voltage and battery charge regulation, pump controls (tank and well water level sensors), and mill operating timer control. System voltage and battery charge regulation a re accomplished by array string switching The pump controls consist of a water level sensor in the water storage tank to stop and start the pump and a water level serisor in the well to stop the pump when the well water level drops below the pump intake. The mill control consists of a timer which will allow the mill to be operated for an accumulated time of 8 hours/day.

In addition to system voltage regulation, under- and over-voltage protection is provided identical to that of the Schuchuli system.

The system contains two types of instrumentation - panel meters and an automatic data logger. Data from these instruments are to be read and recorded daily by the mill operator. The data tapes are to be forwarded to LeRC for reduction and analysis.

Safety features incorporated in the design of the Tangaye system are similar to those described previously for schuchuli.

\section{COSTS}

Photovoltaic system costs are commonly divided into costs associated with (1) the photovoltaic module, and (2) the balance-of-system (BOS). The module is the smallest, electrically interconnected, environmentally protected assembly of solar cells: the basic building block of the solar array. The BOS is composed of the foilowing items:

'Excluded are shipping, electric power distribution lines, and loads powered by the system. 
- Array, Structure, and Site Preparation: module mounting frames; fraine supports and foundations; security and safety equipment; site clearing. levelinj, drainage;

- Electrical: wiring, interconnects; control circuits/instruments; load management circuits; voltage regulation, power conditioning; enclosure or building; bullding;

- Storage: batteries; racks and venting equipment; enclosure or

- Installation and Checkout

o Other: system sizing and design; module test and inspection; packaging and freight preparation; maintenance equipment.

\section{Module Cost}

Based on the May 1978 U.S. General Services Administration (GSA) price schedule, module costs for kilowatt quantities ranged from $\$ 14.70$ to $\$ 18.30 / \mathrm{Wp}$. ' For tens of kilowatts quantity in 1978; the DOE block purchases were about $\$ 13 / \mathrm{Wp}$ (1978 dollars). The DOE module cost projection, in 1978 dollars, is as follows: 1979, \$9/Wp; 1980, \$5/Wp, 1981, $\$ 2.45 / \mathrm{Wp} ; 1986, \$ .61 / \mathrm{Wp}$.

\section{BOS Cost}

Current BOS cost can be ascertained by examining the costs of recently installed photovoltaic systems. The following information is derived from a detailed cost analysis (refs. o and 7) of the systems listed in Table 2, except for the short-term India Educational TV units and the Isle Royale refrigerator. The analys is indicates that BOS costs over the range of PV system power from about 0.4 to $4 \mathrm{kWp}$, are $57 \%$ to $46 \%$ of the total installed system cost. As a check on the cost analyses, three commercial manufacturers of photovoltaic systems were surveyed to obtain BOS costs for a nominal $2 \mathrm{kWp}$ system. The costs were found to be in agreement with those of the above analysis. It was concluded that for recently deployed photovoltaic systems the BOS costs fall in the range of $\$ 11$ to $\$ 17 / W p$ (1978 dollars).

Significant reduction of BOS costs will not be easy. Costs are spread among several major and disparate elements. Thus, the cost reduction of items in any one BOS element will not markedly reduce the total BOS cost. Also, the BOS is composed of materials and parts which are products of relatively mature technology and production. Further, possible cost

'Module peak power, as determined for 60C (140F) cell temperature, $100 \mathrm{~mW}$ / $\mathrm{cm}^{2}$ solar insolation, AMI, measured at 15.8 volts. 
reduction approaches inviiving greater muduie converston efficiency as well as increased BOS standaridization do not unequivocally assure large $B O S$ cost reduction, since tradie-iffs are invelved in most instances. In view of these factors we have macis a conservative projection of $80 S$ cost (1978 dollars) as follows: 1979, \$12/Wp, 1980, \$10/Wp; 1981, \$8/Wp; 1986, $\$ 5 /$ Wp.

\section{Energy Cost}

Photovoltaic. - The installed photovoltaic system costs, projected to 1986, for $60 \mathrm{C}$ iu 10,000 peak watt systems are calculated from module and BOS cost escimates given in the preceeding section. For completeness the calculation includes a levelized annual replacement and maintenance cost conservatively estimated to be about $15 \%$ of the annual capital cost. The following assumptions were made: (1) annual energy output per peak watt, $1.6 \mathrm{kWH} ;(2)$ annuai interest rate, $10 \%$ (ref. 8 ); and (3) systa.n life, 20 years. The resuits are displayed in Table 3 as Levelized Annual Costs and Energy Cost, $\$ / \mathrm{kWH}$.

TABLE 3. - INSTALLEL PHOTOVOLTAIC SYSTEM COST PRQJECTIONS

(1978 \& U.S. PER PEAK WATT)

\begin{tabular}{|c|c|c|c|c|c|}
\hline $\begin{array}{l}\text { MODULE } \\
\text { COST } \\
\end{array}$ & $\begin{array}{l}\text { BOS } \\
\text { COST }\end{array}$ & $\begin{array}{l}\text { TOTAL FIRST } \\
\text { COST } \\
\end{array}$ & $\begin{array}{l}\text { LEVELIZED ANNUAL } \\
\text { CAPITAL COST } \\
\end{array}$ & $\begin{array}{l}\text { LEVELIZED ANNUAL } \\
\text { REPLACEMENT AND } \\
\text { MAINTENANCE } \\
\end{array}$ & $\begin{array}{l}\text { ENERGY } \\
\text { LOST, } \\
\$ / K W H\end{array}$ \\
\hline $\begin{array}{ll}378 & 13.00\end{array}$ & 15,00 & 28.00 & 3.29 & .44 & 2.33 \\
\hline 9.00 & 12.00 & 21.00 & 2.46 & .31 & 1.73 \\
\hline 5.00 & 10.00 & 15.00 & 1.76 & .23 & 1.24 \\
\hline 2.45 & 8.00 & 10.45 & 1.22 & .17 & .86 \\
\hline .61 & 5.00 & 5,61 & .66 & .10 & .47 \\
\hline
\end{tabular}

\section{A)ternative Power Sources}

For purposes of comparison the cost of alternative power sources, namely, diesel/electric and utility powerline extension, are considered.

Diesel/eiectric. - I $\hat{\imath}$ is frequently stated that diesel generators offer a reliable source of electricity and that the initial cost is very low for demands less than $10 \mathrm{~kW}$. To ascertain actual cost experience, a survey was made of several suppliers. This survey indicates that costs, less shipping, ranged from $\$ 2700$ for a $3 \mathrm{KVA}$ yenerator to $\$ 5500$ for a 10 KVA generator, plus $\$ 1000$ for installation. The cost per kilowatt of 
capacity installed thus ranges from $\$ 1200$ per $\mathrm{KW}$ to $\$ 650$ per $\mathrm{kW}$. (Most applications discussed herein require 3 KVA continuous power, or less.) Further, the yearly maintenance costs equal or exceed the initial costs of the diesel generators, based on the recommended matntenance schedule. $91 \mathrm{so}$, experience in the U.S., where fuel is relattvely cheap, indi:ates that for diesel generators run at maximum capacity annual fuel costs equal or exceed first cost of the generator. Lastly, it is recommended practice to provide a second diesel generator on-site as a back-up, to insure power avaliability,

Consideration of only the initial cost of a diesel generator can be . quite misleading. Rather it is necessary to consider the levelized annual cost for the generator, operation and maintenance. In calculating energy costs, the following assumptions are made: (1) 1978 fuel cost, $\$ 2 / g a l$. (based on recent cost in Ouagadougou, Upper Volta); (2) system $11 \mathrm{fe}, 5$ years; (3) annual interest rate, $10 \%$; (4) fuel escalation of $7 \%$ per annum.

Powerline extension. - For calculation of cost of extending a line from an existing transmission line to the point of use, the following assumptions are made: (1) line costs, $\$ 4000 / \mathrm{km}$ (ref. 9); (2) electric energy cost, $\$ .10 / \mathrm{kWH}$; and (3) annual interest rate, $10 \%$.

\section{Cost Comparisons}

Figure 3 shows energy cost versus annual energy consumption for a photovoltaic system and a 3 KVA diesel in 1978 and 1981 . Superimposed on the plot are the annual energy consumption for several applfcations relevant to needs in rural areas of underdeveloped countries. The cost breakeven point for photovoltaics is $4200 \mathrm{kWH}$ and $17,000 \mathrm{kWH}$ annual energy consumption, respectively, in 1978 and 1981.

Figure 4 provides energy cost versus annual energy consumption for photovoltaics versus powerline extension, in 1978 and 1981 . Energy consumption of characteristic applications are superimposed on the plot. The cost breakeven point for photovoltaics is $5400 \mathrm{kWH}$ and $12,000 \mathrm{kWH}$ for 16 and $48 \mathrm{~km}$ line extension, respectively, in 1978; and 12,000 kWH and $>25,000$ inir for 16 and $48 \mathrm{~km}$ extension, respectively, in 1981 .

\section{CONCLUDING REMARKS}

Experience with installed PV systems, which are currently powering a variety of services for users in rural or remote areas, confirms that $P V$ systems can provide a viable approach to meet many of the basic energy needs in underdeveloped countries. PV system technical development is mature, reflected in the exclusive use of commerclally available hardware for the systems described here. PV system reliability, based on evidence accumulated to date, appears to be satisfactory. PV system energy cost, today, is competitive with alte, native power sources for applications requiring an energy consumption of $5000 \mathrm{kWH} /$ year or less. Within this range 
FIGURE 3.

PHOTOVOLTAIC \& DIESEL

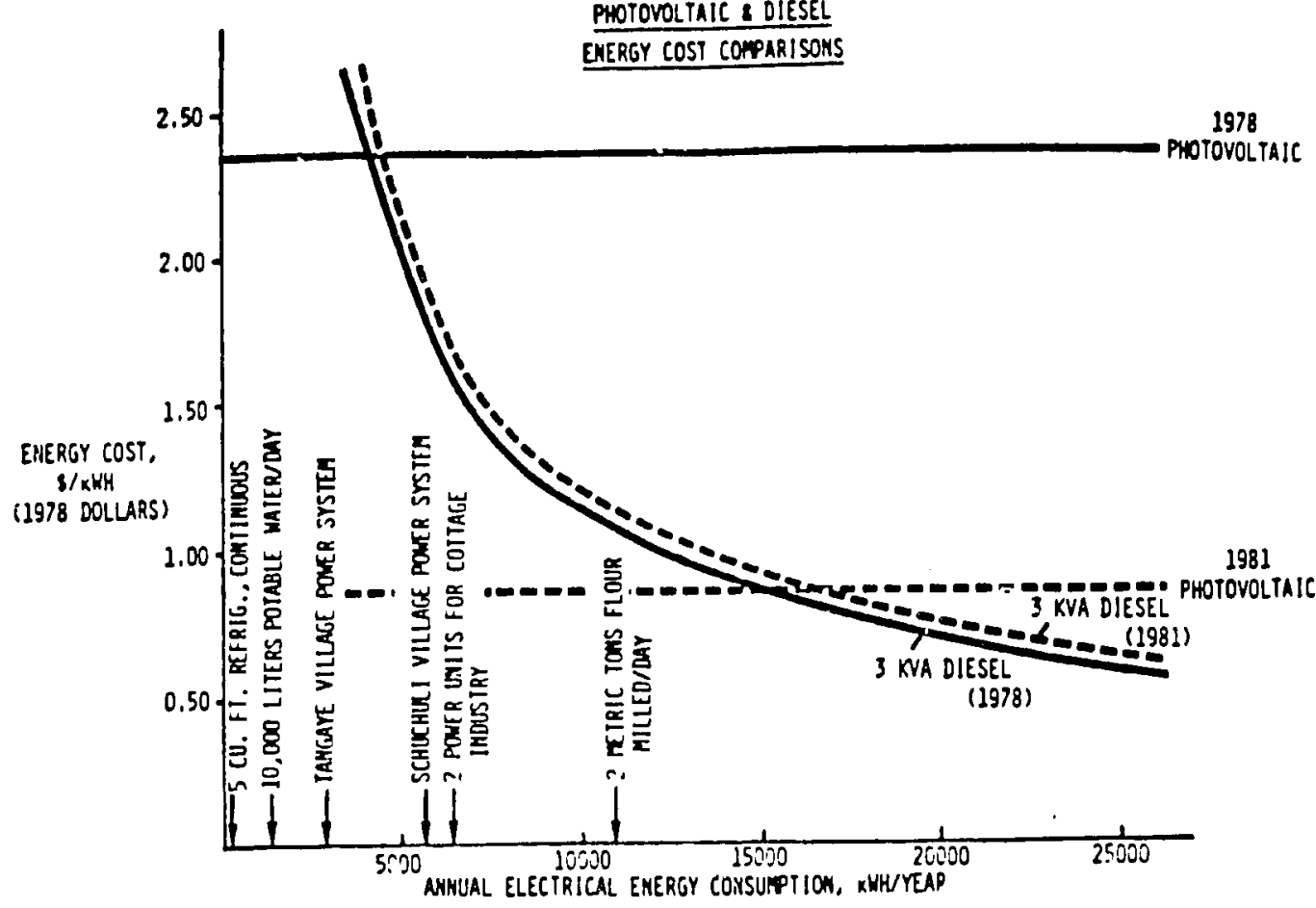

FIOLRE 4.

P-JTJVOLTAIC \& UTILITY EXTE:ISIOR

ENERGY COST COMPARISAYS

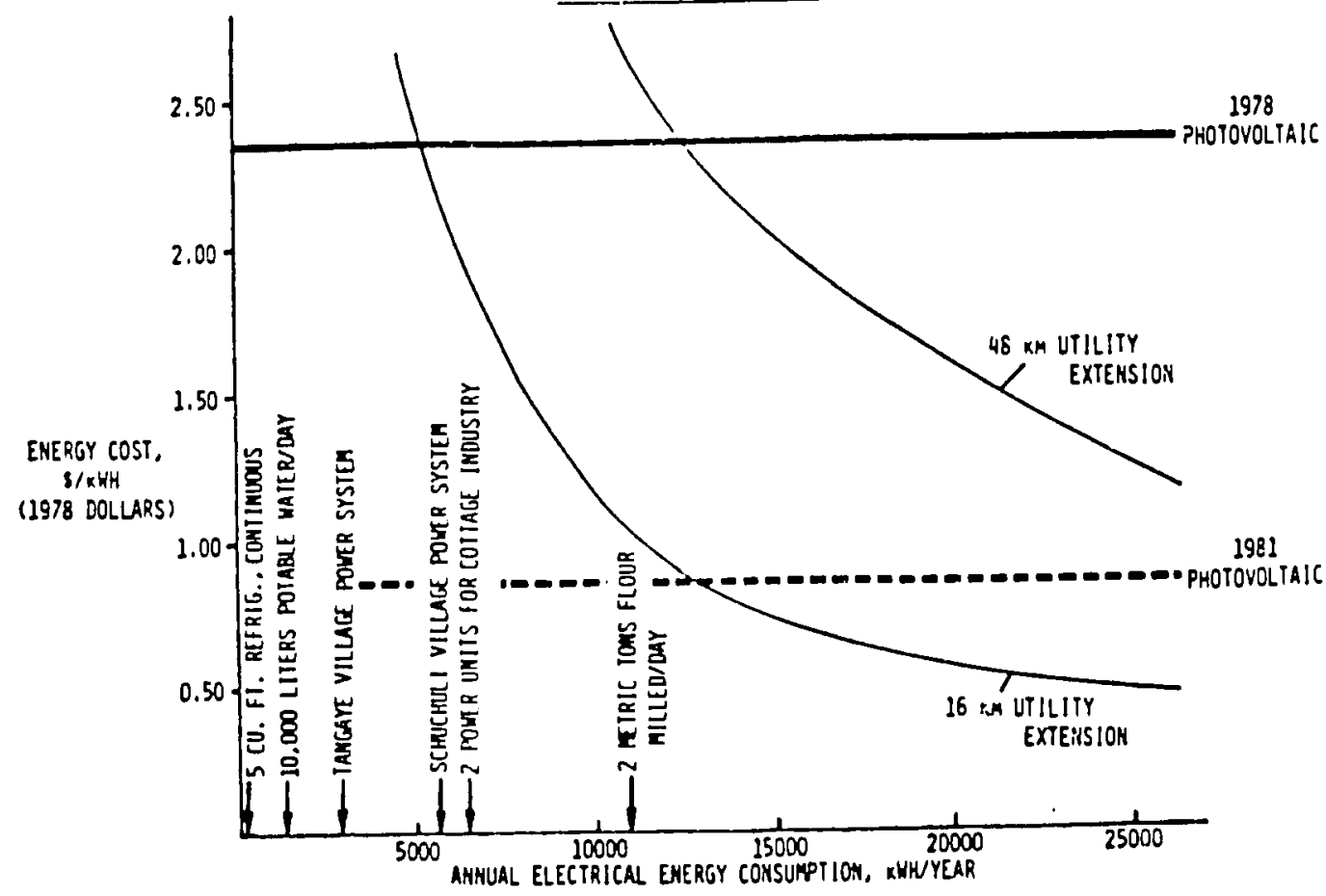


of annual energy consumption lie many important applicatioris relevant to rural areas of underdeveloped countries, see Figures 3 and 4 for examples. Over the next severial years it may be anticipated that PV system eniergy cost will continue to drop steadlly, approaching $\$ .50 / \mathrm{kWH}$ ty 1986 . At that time it is likely that PV systems will be the least expensive source for all decentralized electrical generation in underdeveloped countries.

Inherent modularity permits PV systems to closely match a user's discrete needs for electrical power, from watts to tens of kllowstts or more. Likewise, because of modularity, increments of power may be added as future needs dictate and resources allow. This steprise, incremental option associated with photovoltaics is in sharp contrast with the requirements associated with central generation schemes.

We conclude that photovoltaics must now be viewed as a realistic energy alternative for developing countries. PV power systems hold promise of aidirig current programs for improving quality of life ard increasing economic opportunity for rural populations. And, in the long pull, PV power sj'stems promise a renewable energy resource which could markedly lessen dependence on imported fuels.

\section{REFERENCES}

1. Energy Needs, Uses and Resources in Developing Countries. P. F. Palmedo, et al., BNL 50784, March 1978.

2. Energy and Agriculture in the Third World. A. Makhijani and A. Poole. Bollinger Publishing Co., Cambridge, Mass., 1975.

3. Robert S. McNamara, Address to the Board of Governors of the World Bank, 1976.

4. Japan's Solar Cell Technology is Moving Ahead Rapidly. T. Tsuji. JEE, June 1976.

5. Personal communication with Wright Associates, Inc., Longmont, Co.

6. Impact of Balance of System (BOS) Costs on Photovoltaic Power Systems. $G$. Hein, et al., DOE/NASA/1022-78/40, June 1978 .

7. Cost of Photovoltaic Energy Systems as Determined by Balance-ofSystem Costs. L. Rosenblum. NASA TM-78957, June 1978.

8. Personal communication with Dr. Charles Weiss, World Bank.

9. Rural Electrification, A World Bank Paper, page 5, October 1975. 